\title{
The International Year of Biodiversity
}

\author{
Koen Martens
}

Published online: 24 December 2009

(C) Springer Science+Business Media B.V. 2009

The United Nations declared 2010 to be the International Year of Biodiversity. It is a celebration of life on earth and of the value of biodiversity for our lives. The world is invited to take action in 2010 to safeguard the variety of life on earth: biodiversity. (http://www.cbd. int/2010/welcome/)

Whereas 2009 celebrated both the 200th anniversary of Charles Darwin and the 150th of the publication of his most famous book, On the origin of species ..., 2010 will celebrate the biodiversity on our planet. Whether or not this sequel was intentional, it is certainly most fitting, because evolution as a process lies at the basis of the patterns of biodiversity. In addition, this biodiversity needs our attention, urgently. Since the Convention on Biological Diversity was drafted and signed in Rio in 1992, conservation of biodiversity has tumbled down the list of international priorities, to the extent that, recently, it is tucked away in a little corner of the 'climate change' bullet. It is high time that biodiversity was put on the agenda again, somewhere very high up, as biodiversity is still very much threatened, in spite of 16 years of growing awareness.

K. Martens ( $\square)$

Royal Belgian Institute of Natural Sciences, Freshwater Biology, Vautierstraat 29, 1000 Brussels, Belgium

e-mail: martens@naturalsciences.be

\section{The paradox of freshwater biodiversity}

This is especially true for aquatic biodiversity. Nonmarine aquatic habitats comprise only $0.01 \%$ of the worlds' water and cover only $8 \%$ of the Earth's surface. Yet $6 \%$ of all species, and more than $10 \%$ of all animal species, occur in freshwater, including $25 \%$ of all vertebrates and $40 \%$ of all fish (Balian et al., 2008a). This imbalance of 1-2 orders of magnitude between surface and diversity can be called the 'paradox of freshwater biodiversity'. The extinction rate in freshwater ecosystems is estimated at $4 \%$ per decade in North America (Ricardi \& Rasmussen, 1999); 32\% of all species of Amphibia are threatened with extinction. Freshwaters are richer, but also more threatened (Dudgeon et al., 2006).

This is not owing to lack of scientific interest in biodiversity issues. The special Hydrobiologia volume (Balian et al., 2008b), the Freshwater Animal Diversity Assessment, is a case in point: out of the 10 most cited Hydrobiologia papers from 2008, five are from this FADA volume, including the top three. In our trade, biodiversity remains a very hot topic. Hydrobiologia will also contribute to the biodiversity year, with the publication of two special issues.

Fifty years ago, Evelyn Hutchinson gave a presidential talk to the Society of Naturalists (and wrote the subsequent paper) with the title 'Homage to Santa Rosalia or why are there so many kinds of animals?' In it, Hutchinson touches upon many topics, most of which are still relevant to biodiversity. Luigi 
Naselli-Flores, himself a Hydrobiologia editor and living in Palermo close to the Santa Rosalia, decided, together with Giampaulo Rossetti, to edit a special issue of Hydrobiologia, commemorating the birthday of this seminal paper.

The second special volume is the result of a sadder occasion. At the end of August 2009, Professor Stanley Dodson, editor of Hydrobiologia, died in a fatal accident (see the obituary in Havel, 2009). Many of his friends and colleagues decided to honour him by contributing to a memorial issue in Hydrobiologia. The main guest editor of this volume is the previous editor-in-chief of the journal, and life-long friend of Stanley, Henri Dumont.

Both of these volumes are scheduled for 2010 .

\section{Other Hydrobiologia initiatives}

When the present issue of Hydrobiologia (vol. 637) appears, we will have had 5,000 manuscripts submitted through the Editorial Manager system since we started to use it in January 2003. Of these, we have been able to publish about a third. Together with the rising impact factor (from 0.653 in 2004 to 1.449 in 2008), the rate of submissions also increased dramatically (less than 600 submissions through Editorial Manager in 2004, more than 900 in 2009). The journal is doing well, and continues to adapt to the ever-changing landscape of scientific publishing. Today, the editors and publishers of Hydrobiologia are happy to announce two further initiatives.

First, we herewith call upon all authors to submit Opinion and Review Papers to the journal. These papers will open regular issues and we are pleased to announce that all Opinions and Reviews submitted and accepted in 2010 will receive free promotional open access!

Second, we wish to deviate from mainstream scientific publishing by opening our journal to papers with negative results (e.g. on an experiment which fails to corroborate a hypothesis). The Commission on Publication Ethics (COPE; http://publicationethics. org/) has identified the general reluctance to publish negative results as being close to 'scientific fraud', and we agree with this. Negative results are also scientific results, and should also be published. If such results remain unpublished, other scientists will not know about them and might develop the same experiment. This is redundant research and there is not too much research money around... Therefore, we encourage you to prepare such results on aquatic habitats and biota as Short Research Notes (c. 1,500 words, one table and/ or figure plus supplementary online material-see instructions to authors on Hydrobiologia website) and to submit them to us.

Finally, we take this opportunity to thank all authors who submitted manuscripts and all 1,000 referees who worked for our journal in 2009. The work of referees is vital for the future of science in general; without this system of reciprocal altruism, the present concept of scientific publishing will fall apart. We refrain from publishing the list of all referees that have worked for the journal during the past year, as this might breach anonymity, but we applaud all those who have made the effort!

\section{References}

Balian, E., H. Segers, C. Lévèque \& K. Martens, 2008a. The freshwater animal diversity assessment: an overview of the results. In Balian, E. et al. (eds), Freshwater Animal Diversity Assessment. Hydrobiologia 595: 627-637.

Balian, E., H. Segers, C. Lévèque \& K. Martens, 2008b. Freshwater animal diversity assessment. Hydrobiologia 595: $637 \mathrm{pp}$.

Dudgeon, D., A. H. Arthington, M. O. Gessner, Z.-I. Kawabata, D. J. Knowler, C. Lévêque, R. J. Naiman, A.-H. PrieurRichard, D. Soto, M. L. J. Stiassny \& C. A. Sullivan, 2006. Freshwater biodiversity: importance, threats, status and conservation challenges. Conservation Biology 81: $163-182$.

Havel, J. E., 2009. Stanley Ivan Dodson: distinguished ecologist, naturalist and teacher. Hydrobiologia 636: 1-6.

Ricardi, A. \& J. B. Rasmussen, 1999. Extinction rates of North American freshwater fauna. Conservation Biology 13(5): 1220-1222. 